\title{
PRODUCT LIABILITY TERHADAP SMART PHONE TANPA FASILITAS PURNA JUAL BERUPA GARANSI TERKAIT PENCANTUMAN KLAUSULA EKSONERASI DALAM PERJANJIAN BAKU
}

\author{
Si Ngurah Ardhya \\ Jurusan Ilmu HukumUniversitas Pendidikan Ganesha Singaraja \\ Email: genethicsbali@yahoo.com
}

\begin{abstract}
ABSTRAK
Penelitian ini bertujuan untuk mengetahui: (1) Apakah penerapan prinsip product liability dalam transaksi smart phone di Denpasar sudah efektif? (2) Bagaimana relevansi pencantuman klausula eksonerasi dalam transaksi smart phone di Denpasar? Jenis penelitian yang digunakan adalah penelitian hukum empiris yang bersifat deskriptif. Penentuan sampel yang digunakan adalah non probability sampling dengan bentuk snowball sampling yakni penarikan sampel didasarkan pada penunjukan atau rekomendasi dari sampel sebelumnya, tidak ada ketentuan pasti dalam bentuk angka atau prosentase mengenai jumlah sampel yang akan diteliti, besarnya jumlah sampel didasarkan atas titik jenuh. Pengolahan dan analisa data dilakukan secara deskriptif kualitatif. Berdasarkan penelitian dapat diketahui bahwa implementasi ketentuan product liability belum efektif diterapkan oleh pelaku usaha di Denpasar akibat lemahnya pengawasan yang dilakukan oleh struktur hukum serta lemahnya budaya hukum masyarakat khususnya pelaku usaha terkait pemahaman mengenai kewajiban dan tanggung jawab dalam menjalankan usaha. Klausula eksonerasi yang dicantumkan pelaku usaha tidak relevan karena memenuhi unsur terlarang dari ketentuan Pasal 18 ayat (1) huruf b UUPK. Pelanggaran pencantuman klausula eksonerasi ini sebagai akibat dari kurangnya kredibilitas struktur hukum karena pengawasan yang dilakukan hanya bersifat pasif yakni menunggu adanya pengaduan dari masyarakat.
\end{abstract}

Kata kunci: jual-beli, tanggung jawab produk, perjanjian baku, klausula eksonerasi.

\section{ABSTRACT}

This research aims to determine: (1) Has the application of product liability principles in smart phone transactions in Denpasar been effective? (2) How is its relevance of the inclusion of exemption clause in smart phone transactions in Denpasar? The adopted type of study is the descriptive empirical legal study. The non-probability sampling in form of snowball sampling is used to determine samples, namely the samples were taken based on the nomination or recommendation from the previous samples. There are not any definite provisions concerning the number or percentage concerning the total samples to be studied. The total samples are determined based on the leveling-off points. The data are processed and analyzed qualitatively and descriptively. The study findings are that product liability provisions have not been implemented effectively by merchants in Denpasar due to weak supervision of law structure and lack of legal culture awareness among community members especially those of merchants in relation to their liability and responsibility to run businesses. The exemption clause determined by the merchants 
are not relevant because they violate the provision of article 18 paragraph (1) letter $b$ of Customer Protection Law. The violation of inclusion the exemption clause happened due to lack of credibility of law structure and passive supervision, namely just waiting for the complaints from community members.

Keywords: contract of sale, product liability, standard contract, exemption clause.

\section{Pendahuluan}

Perkembangan teknologi dari tahun ke tahun terus mengalami kemajuan yang ditandai dengan semakin banyaknya produk barang elektronik yang telah dihasilkan. Kondisi seperti ini tentunya menguntungkan konsumen, karena produk barang elektronik yang dihasilkan mampu menunjang aktivitas masyarakat. Adapun salah satu produk barang elektronik yang 5 (lima) tahun terakhir terus dikembangkan yakni smart phone. Smart phone merupakan telepon genggam dengan kemampuan dan fungsi tingkat tinggi menyerupai komputer yang bekerja menggunakan seluruh piranti lunak sistem operasi yang menyediakan hubungan standar dan mendasar bagi pengembang aplikasi (Fadjar Efendy Rasjid, 2017). Fungsi smart phone sangat beragam, yakni mulai dari alat komunikasi (dalam bentuk telepon suara, mengirim pesan SMS, pesan MMS, dan layanan data); sebagai media informasi (dalam bentuk fasilitas koneksi internet tanpa kabel); sebagai media hiburan (dapat menayangkan berbagai format multimedia); sebagai media aplikasi (memasang dan menjalankan berbagai aplikasi, misal aplikasi penunjuk arah dan/atau peta sepeti google maps); sebagai media penyimpanan data (seperti halnya pada USB flashdisk, USB external drive dan multimedia card); hingga fungsi yang semata-mata hanya untuk menunjang penampilan seharihari (fashion).
Sejak awal kemunculan produk smart phone sebagaimana dimaksud diatas, hingga saat ini khususnya di Denpasar cukup banyak pelaku usaha yang memperjual-belikan produk tersebut. Hal ini dilatarbelakangi oleh asumsi pelaku usaha, bahwa Kota Denpasar cukup strategis menjadi basis peredaran produk smart phone mengingat kepadatan jumlah penduduknya. Adapun smart phone yang diperjual-belikan terdiri dari berbagai brand, mulai dari brand ternama hingga brand pendatang baru sebagai pesaing. Berdasarkan hasil observasi, diketahui bahwa paling sedikit ada 13 (tiga belas) brand produk smart phone yang telah diperjualbelikan oleh pelaku usaha di Denpasar. Masing-masing brand saling bersaing dalam hal menarik minat konsumen, mulai dari menawarkan berbagai tingkatan spesifikasi yang variatif disesuaikan dengan kebutuhan konsumen, hingga menawarkan desain yang elegant dengan harga yang terjangkau. Desain elegant dengan harga yang terjangkau menjadi manufer dari brand pendatang baru, hal ini menjadi daya tarik tersendiri bagi kalangan konsumen tertentu. Dengan munculnya brand pendatang baru sebagaimana dimaksud diatas dapat dikatakan bahwa saat ini smart phone tidak lagi menjadi barang yang mewah sebagaimana diawal peredarannya, dimana pelaku usaha nampaknya sangat memperhitungkan kemampuan finansial calon konsumennya. 
Berdasarkan hasil observasi, ternyata harapan setiap pelaku usaha yang menjadikan Kota Denpasar sebagai basis peredaran produknya tidak bertepuk sebelah tangan. Hal ini dapat diamati dari data transaksi 3 (tiga) bulan terakhir ditahun 2016 pada beberapa pelaku usaha penjual produk smart phone di Denpasar. Berdasarkan data sebagaimana dimaksud diatas diketahui bahwa minimal transaksi yang terjadi per-harinya adalah paling sedikit 18 (delapan belas) transaksi atas berbagai variant produk smart phone yang ditawarkan dari masing-masing brand. Adapun brand yang mendominasi jumlah transaksi smart phone pada pelaku usaha sebagaimana dimaksud diatas adalah brand pendatang baru. Kondisi seperti ini menunjukkan bahwa minat konsumen akan produk smart phone khususnya terhadap brand sebagaimana dimaksud diatas tergolong tinggi. Hal ini tentu tidak terlepas dari manufer pelaku usaha sebagaimana telah disampaikan sebelumnya, dimana pelaku usaha dalam memproduksi dan memasarkan produknya sangat memperhitungkan kebutuhan dan kemampuan finansial calon konsumennya.

Beranjak dari pesatnya pertumbuhan pelaku usaha yang sejalan dengan tingginya minat konsumen di Denpasar terhadap smart phone, hal ini berdampak pada banyaknya jumlah transaksi yang terjadi di Denpasar. Kondisi sebagaimana dimaksud diatas tentu merupakan suatu harapan pelaku usaha yang telah terpenuhi, dimana diselenggarakannya suatu kegiatan usaha adalah untuk mendistribusikan suatu pruduk sampai pada konsumen dengan tujuan mendapatkan keuntungan. Namun demikian perlu digaris bawahi bahwa selain fokus pada tujuan mendapatkan keuntungan, pelaku usaha juga harus memperhatikan dan mengimplementasikan kewajiban serta tanggung jawabnya, terutama tanggung jawab terhadap setiap kerugian yang diderita konsumen akibat produk cacat (selanjutnya disebut dengan istilah product liability). Secara normatif dalam bentuk suatu Peraturan PerundangUndangan (selanjutnya disingkat PerUU), terkait mengenai kewajiban pelaku usaha sebenarnya telah diatur dalam Undang-Undang Republik Indonesia No. 8 Tahun 1999 Tentang Perlindungan Konsumen (selanjutnya disingkat UUPK), yakni pada Pasal (selanjutnya disingkat Ps.) Ps. 7 UUPK. Terkait dengan product liability, secara normatif diatur dalam Ps. 19 UUPK yang pada ayat (1) menyatakan bahwa pelaku usaha bertanggung jawab memberikan ganti rugi atas kerusakan, pencemaran, dan atau kerugian konsumen akibat mengkonsumsi barang dan atau jasa yang dihasilkan atau diperdagangkan. Secara garis besarnya, product liability merupakan tanggung jawab secara hukum dari orang atau badan hukum yang menghasilkan produk dan/atau orang maupun badan hukum yang menjual atau mendistribusikan produk, terhadap konsumen yang mengalami kerugian akibat produk cacat (Adrian Sutedi, 2008: 65).

Secara umum dalam prakteknya, product liability biasanya diimplementasikan dalam bentuk fasilitas purna jual berupa garansi. Dalam hal ini garansi diasumsikan sebagai pernyataan tanggung jawab pelaku usaha terhadap setiap kemungkinan kerugian berupa kerusakan yang diderita konsumen dikemudian hari. Ketentuan Ps. 25 ayat (1) UUPK menyatakan bahwa pelaku usaha yang memproduksi barang yang pemanfaatannya berkelanjutan dalam batas waktu sekurang-kurangnya 1 
(satu) tahun wajib menyediakan suku cadang dan/atau fasilitas purna jual dan wajib memenuhi jaminan atau garansi sesuai dengan yang diperjanjikan. Hal ini memberi arti bahwa jaminan atau garansi sebagai bentuk tanggung jawab pelaku usaha wajib dipenuhi apabila keberadaan jaminan atau garansi sebagaimana dimaksud diatas sebelumnya telah diperjanjikan antara pihak pelaku usaha dan konsumen. Apabila merujuk pada prinsip product liability dalam Ps. 19 UUPK, maka baik diperjanjikan atau tidaknya jaminan maupun garansi oleh pelaku usaha tidak menjadi dasar pertanggung jawaban pelaku usaha terhadap kerugian konsumen, karena product liability menganut sistem tanggung jawab mutlak (strict liability) yang artinya bahwa pelaku usaha langsung dianggap bersalah (presumption of fault) dan harus bertanggung jawab (liable) untuk memberi ganti rugi secara langsung kepada konsumen yang mengalami kerugian.

Memperhatikan Prinsip product liability yang secara umum di implementasikan dalam bentuk fasilitas purna jual berupa garansi sebagaimana telah dipaparkan diatas, apabila dikaitkan dengan realitas yang terjadi dilapangan, ternyata tidak semua pelaku usaha memberikan fasilitas purnajual berupa garansi sebagai bentuk pernyataan product liability terhadap produk smart phone yang di perjual-belikannya. Dalam hal ini ada brand tertentu dari produk smart phone yang tidak disertakan garansi. Dengan tidak disertakannya garansi tersebut, pelaku usaha menolak setiap tuntutan ganti kerugian konsumen. Adapun penolakan pelaku usaha sebagaimana dimaksud diatas, ternyata juga dinyatakan secara eksplisit dalam bentuk klausula eksonerasi pada setiap perjanjian baku yang telah dipersiapkan sebelumnya dalam bentuk formulir berupa nota, faktur dan/atau invoice. Klausula eksonerasi yang dicantumkan pelaku usaha menyatakan bahwa, pelaku usaha berhak menolak atas pengembalian barang yang telah dibeli konsumen dan/atau bahwa barang yang telah dibeli konsumen tidak dapat ditukar atau dikembalikan. Dengan adanya klausula eksonerasi sebagaimana dimaksud diatas, terhadap konsumen yang awam akan hukum tentu tidak menyadari akan hak-haknya, sehingga konsumen dengan terpaksa menerima penolakan tersebut sebagai suatu konsekuensi.

Terkait penerapan perjanjian baku dalam dunia usaha, tidak dapat dipungkiri bahwa hal tersebut memberi dampak positif berupa efisiensi waktu bernegosiasi dan/atau bertransaksi. Perjanjian baku merupakan perjanjian tertulis yg telah digandakan berupa formulir yang isinya telah distandarisasi atau dibakukan terlebih dahulu secara sepihak oleh pihak yang menawarkan dan ditawarkan secara masal tanpa mempertimbangkan perbedaan kondisi yang dimiliki konsumen (Hasanuddin Rahman, 2000: 134). Isi perjanjian yang telah distandarisasi atau dibakukan sebagaimana dimaksud diatas dikenal dengan istilah klausula baku. Klausula baku biasanya berupa aturan atau ketentuan dan syarat-syarat yang mengikat dan wajib dipenuhi oleh konsumen. Dasar pengaturan pencantuman klausula baku adalah ketentuan Ps. 18 UUPK yang merupakan ketentuan khusus (lex specialis) terhadap ketentuan Pasal 1320 jo. Pasal 1337 KUHPerdata yang merupakan lege generali-nya. Hal ini berarti bahwa penerapan klausula baku adalah sah menurut hukum meski seringkali dianggap mengenyampingkan asas kebebasan berkontrak selama tidak memenuhi unsur yang dilarang 
sebagaimana diatur dalam Ketentuan Ps.18 ayat (1) dan ayat (2) UUPK. Maksud dari ketentuan Ps. 18 ayat (1) UUPK ini adalah untuk mencegah pelaku usaha mencantumkan klausula yang berisi tentang pembatasan tanggung jawab dan/atau mencegah pelaku usaha untuk mencantumkan klausula yang mengandung syarat khusus membebaskan dirinya dari tanggung jawab terhadap akibat yang merugikan konsumen yang timbul dari pelaksanaan perjanjian (Mariam Darus Badrulzaman, 2001: 55).

Dalam hal penerapan perjanjian baku pelaku usaha seringkali melakukan penyalahgunaan keadaan, dimana penyalahgunaan keadaan ini sangat merugikan pihak konsumen. Ada 2 (dua) unsur penyalahgunaan keadaan, yakni: (1). Kerugian bagi satu pihak; (2). Penyalahgunaan kesempatan oleh pihak lain(H.P. Panggabean, 2010: 75). Dari unsur yang ke-2 (dua), timbul 2 (dua) sifat perbuatan yakni: (1). Penyalahgunaan keunggulan ekonomis dimana suatu pihak mempunyai keunggulan ekonomis terhadap pihak lainnya sehingga pihak lain terpaksa mengadakan perjanjian; (2). Penyalahgunaan keunggulan kejiwaan dimana salah satu pihak menyalahgunakan keadaan jiwa yang istimewa dari pihak lawan seperti tidak berpengalaman, dan kurang pengetahuan. Memperhatikan asas keadilan dan keseimbangan (Ps. 2 UUPK); memperhatikan hak konsumen untuk diperlakukan atau dilayani secara benar dan jujur serta tidak diskriminatif (Ps. 4 huruf (g) UUPK), serta memperhatikan ketentuan Ps. 15 UUPK yang menyatakan bahwa dalam menawarkan barang pelaku usaha dilarang melakukan dengan cara pemaksaan atau cara lain yang dapat menimbulkan gangguan fisik maupun psikis terhadap konsumen, dengan demikian dari ketentuan-ketentuan ini secara jelas dapat ditafsirkan sebagai keterkaitan atas larangan penyalahgunaan keadaan. Adapun keberadaan Ps. 18 UUPK yang mengatur mengenai pencantuman klausula baku juga ditujukan untuk mencegah terjadinya penyalahgunaan keadaan oleh pihak yang memiliki kedudukan lebih kuat.

Berdasarkan apa yang telah diuraikan diatas dengan melihat kondisi yang sangat merugikan konsumen, dimana terjadi kesenjangan antara das sollen dan das sein maka perlu dilakukan pengkajian secara yuridis terhadap permasalahan tersebut guna mengetahui penerapan prinsip product liability dan relevansi pencantuman klausula eksonerasi dalam perjanjian baku.

\section{Metode Penelitian}

Jenis penelitian ini adalah penelitian hukum empiris, yakni penelitian dilakukan beranjak dari adanya kesenjangan antara das sollen dan das sein. Adapun sifat penelitian ini adalah deskriptif, yakni bertujuan menggambarkan secara tepat sifat-sifat suatu individu, keadaan, menentukan penyebaran suatu gejala, atau menentukan ada tidaknya hubungan antara suatu gejala dengan gejala lain dalam masyarakat (Amiruddin dan $\mathrm{H}$. Zainal Asikin, 2010: 25). Data yang digunakan adalah data primer, yakni data yang diperoleh secara langsung dilapangan baik dari responden maupun informan; dan data sekunder, yakni data yang diperoleh melalui penelitian kepustakaan (Library Research) (Soerjono Soekanto dan Sri Mahmudji, 2013: 13). Teknik pengumpulan data yang digunakan yakni teknik studi dokumen, teknik observasi, dan teknik wawancara (Amiruddin dan H. Zainal Asikin, 2010: 
82). Teknik pengambilan sampel yang digunakan adalah non probability sampling dalam bentuk snowball sampling, jadi tidak ada ketentuan yang pasti baik dalam bentuk angka ataupun prosentase mengenai jumlah sampel yang akan diteliti, besarnya jumlah sampel yang diteliti didasarkan atas titik jenuh, yang mana penelitian akan dihentikan dan dianggap telah mewakili keseluruhan objek penelitian bila jawaban-jawaban dari para responden maupun informan telah ada kesamaan atau kemiripan (Soerjono Soekanto, 2012: 73). Apabila keseluruhan data yang diperoleh baik dari data primer maupun data sekunder sudah terkumpul, data-data tersebut dianalisis melalui proses pengolah, pemisahan, pengelompokan, serta memadukan sejumlah data yang telah dikumpulkan (Mukhtar, 2013: 120). Data-data yang ada dihubungkan satu sama lainnya, dilakukan interprestasi untuk memahami makna data dalam situasi sosial, kemudian dilakukan suatu penafsiran. Setelah dilakukan analisa secara kualitatif, selanjutnya data disajikan secara deskriptif kualitatif dan sistematis guna mendapatkan kesimpulan sebagai akhir dari penulisan penelitian ini.

\section{Pembahasan}

\section{Penerapan Prinsip Product Liability Dalam Transaksi Smart Phone di Denpasar}

Pada umumnya produk barang yang sampai ke tangan konsumen telah melalui tahap kegiatan perdagangan yang panjang mulai dari produsen, principal, agen, distributor, pelaku usaha retail, dan terakhir barulah sampai pada konsumen. Setiap konsumen dalam usahanya untuk mendapatkan produk barang dari pelaku usaha tentu melalui suatu proses, yang dikenal dengan jual-beli.
Jual-beli adalah suatu perjanjian yang dibuat antara pihak penjual dan pihak pembeli, dimana dalam perjanjian itu pihak penjual berkewajiban untuk menyerahkan objek jual-beli kepada pembeli dan berhak menerima harga, sedangkan pembeli berkewajiban untuk membayar harga dan berhak menerima objek tersebut (Salim H.S., 2003: 49). Hak utama penjual adalah menerima harga dari pembeli atas barang yang telah dijualnya kepada pembeli, sedangkan kewajiban utama penjual adalah menyerahkan barangnya dan menanggungnya, hal ini diatur dalam Ps. 1474 Kitab Undang-Undang Hukum Perdata (selanjutnya disingkat KUHPdt). Yang dimaksud dengan kewajiban untuk menanggung dalam hal ini adalah untuk menjamin dua hal, yakni: (1). Penguasaan benda yang dijual secara aman dan tenteram; (2). Penanggungan terhadap adanya cacat tersembunyi yang menerbitkan alasan untuk pembatalan pembelian (Ps. 1491 KUHPdt). Apabila pada saat transaksi tidak diperjanjikan mengenai penanggungan sebagaimana dimaksud diatas, meski demikian demi hukum penjual diwajibkan untuk menanggung pembeli (Ps. 1492 KUHPdt). Hal tersebut memberi arti bahwa meski tidak ada perjanjian antara penjual dan pembeli mengenai tanggung jawab produk dan/atau tidak diperjanjikannya fasilitas purnajual berupa garansi, namun secara hukum penjual tetap harus bertanggungjawab kepada pembeli bilamana pembeli mengalami kerugian akibat menggunakan produk yang diperjual-belikannya.

Berkaitan dengan penanggungan terhadap adanya cacat tersembunyi, meskipun penjual tidak mengetahui adanya cacat tersembunyi pada produk yang diperdagangkannya, ia tetap diwajibkan menanggung cacat tersebut (Ps. 1506 KUHPdt). Hal ini memberi 
konsekuensi bahwa, terhadap setiap pembeli (selanjutnya disebut konsumen) yang mengalami kerugian akibat adanya cacat tersembunyi dari barang yang dibelinya dari penjual (selanjutnya disebut pelaku usaha), dapat mengembalikan barang tersebut dan menuntut kembali keseluruhan harga pembeliannya dan/atau konsumen dapat menuntut sebagian harga pembeliannya dan tetap memiliki barangnya (Ps. 1507 KUHPdt). Dengan kata lain, bilamana pelaku usaha tidak mengetahui adanya cacat tersembunyi pada produk yang diperdagangkannya, ia hanya diwajibkan untuk mengembalikan harga pembeliannya dan mengganti biaya yang dikeluarkan oleh konsumen untuk penyelenggaraan pembelian (Ps. 1509 KUHPdt). Sebaliknya, apabila pelaku usaha sebenarnya telah mengetahui ada cacat tersembunyi pada barangnya namun tetap menjualnya kepada konsumen, maka selain diwajibkan mengembalikan harga pembeliannya pelaku usaha juga diwajibkan mengganti semua kerugian yang diderita oleh konsumen (Ps. 1508 KUHPdt).

Sejalan dengan hak dan kewajiban pelaku usaha dalam jual-beli, konsumen juga memiliki hak dan kewajiban yang saling bertimbal balik dengan pelaku usaha. Hak utama dari konsumen adalah menerima barang yang telah dibelinya, baik secara nyata maupun secara yuridis. Sedangkan yang menjadi kewajiban utama konsumen adalah membayar harga pembelian pada waktu dan tempat sebagaimana ditetapkan berdasarkan perjanjian (Ps. 1513 KUHPdt). Apabila saat membuat perjanjian tidak ditentukan mengenai waktu dan tempat pembayaran harga pembelian maka konsumen harus membayar di tempat dan waktu dimana penyerahan harus dilakukan (Ps. 1514 KUHPdt).
Selain diatur dalam KUHPdt, adapun mengenai hak dan kewajiban baik bagi konsumen maupun pelaku usaha telah diatur secara khusus dalam UUPK. Berdasarkan ketentuan Ps. 4 UUPK, adapun yang menjadi hak konsumen adalah sebagai berikut:

a. Hak atas kenyamanan, keamanan, dan keselamatan dalam mengonsumsi barang dan/atau jasa;

b. Hak untuk memilih barang dan/atau jasa serta mendapatkan barang dan/atau jasa tersebut sesuai dengan nilai tukar dan kondisi serta jaminan yang dijanjikan;

c. Hak atas informasi yang benar, jelas, dan jujur mengenai kondisi dan jaminan barang dan/atau jasa;

d. Hak untuk didengar pendapat dan keluhannya atas barang dan/jasa yang digunakan;

e. Hak untuk mendapatkan advokasi, perlindungan, dan upaya penyelesaian sengketa perlindungan konsumen secara patut;

f. Hak untuk mendapat pembinaan dan pendidikan konsumen;

g. Hak untuk diperlakukan atau dilayani secara benar dan jujur serta tidak diskriminatif;

h. Hak untuk mendapatkan kompensasi, ganti rugi dan/atau penggantian, apabila barang dan/atau jasa yang diterima tidak sesuai dengan perjanjian atau tidak sebagaimana mestinya;

i. Hak-hak yang diatur dalam ketentuan peraturan perundangundangan lainnya.

Terkait hak konsumen yang diatur dalam Ps. 4 UUPK khususnya pada huruf (h), dimaksudkan untuk memulihkan keadaan yang telah menjadi rusak dan/atau tidak seimbang akibat adanya penggunaan barang atau jasa yang tidak memenuhi harapan 
konsumen. Hak ini sangat terkait dengan penggunaan produk yang telah merugikan konsumen, baik berupa kerugian materi, maupun kerugian yang menyangkut diri seperti: sakit, cacat, dan bahkan kematian konsumen. Untuk merealisasikan hak ini tentu saja harus melalui prosedur tertentu, baik yang diselesaikan secara damai di luar pengadilan (non litigasi) maupun yang diselesaikan melalui pengadilan (litigasi). Rumusan hak-hak konsumen yang telah dikemukakan diatas secara garis besarnya dapat dibagi dalam tiga hak yang menjadi prinsip dasar, yaitu:

1. Hak yang dimaksudkan untuk mencegah konsumen dari kerugian, baik kerugian personal, maupun kerugian harta kekayaan;

2. Hak untuk memperoleh barang dan/atau jasa dengan harga yang wajar;

3. Hak untuk memperoleh penyelesaian yang patut terhadap permasalahan yang dihadapi.

Oleh karena ketiga hak atau prinsip dasar tersebut merupakan himpunan beberapa hak konsumen sebagaimana diatur dalam UUPK, maka hal tersebut sangat esensial bagi konsumen, sehingga dapat dijadikan prinsip perlindungan hukum bagi konsumen di Indonesia. Apabila konsumen akan benar-benar dilindungi, maka hak-hak konsumen yang disebutkan di atas harus dipenuhi, baik oleh pemerintah maupun oleh pelaku usaha, karena pemenuhan hak-hak konsumen tersebut akan melindungi konsumen dari berbagai aspek. Sejalan dengan haknya konsumen juga dibebankan atas kewajiban sebagaimana ditentukan dalam Ps. 5 UUPK, adapun yang menjadi kewajiban konsumen adalah sebagai berikut:

a. Membaca atau mengikuti petunjuk informasi dan prosedur pemakaian atau pemanfaatan barang dan/atau jasa, demi keamanan dan keselamatan;

b. Beritikad baik dalam melakukan transaksi pembelian barang dan/atau jasa;

c. Membayar sesuai dengan nilai tukar yang disepakati;

d. Mengikuti upaya penyelesaian hukum sengketa perlindungan konsumen secara patut.

Meskipun UUPK terkesan menitik beratkan perlindungan terhadap hakhak yang dimiliki konsumen, namun demikian didalamnya juga diatur mengenai hak-hak pelaku usaha yang serta merta harus dilindungi. Berdasarkan ketentuan Ps. 6 UUPK, adapun yang menjadi hak pelaku usaha adalah sebagai berikut:

a. Hak untuk menerima pembayaran yang sesuai dengan kesepakatan mengenai kondisi dan nilai tukar barang dan/atau jasa yang diperdagangkan;

b. Hak untuk mendapat perlindungan hukum dari tindakan konsumen yang beritikad tidak baik;

c. Hak untuk melakukan pembelaan diri sepatutnya di dalam penyelesaian hukum sengketa konsumen;

d. Hak untuk rehabilitasi nama baik apabila terbukti secara hukum bahwa kerugian konsumen tidak diakibatkan oleh barang dan/atau jasa yang diperdagangkan;

e. Hak-hak yang diatur dalam ketentuan peraturan perundangundangan lainnya.

Terkait dengan hak-hak pelaku usaha sebagaimana dijabarkan diatas, khususnya pada huruf (b), huruf (c), dan huruf (d) adalah merupakan hakhak yang lebih banyak berhubungan dengan pihak aparat pemerintah dan/atau Badan Penyelesaian Sengketa Konsumen (selanjutnya disingkat BPSK) atau pengadilan dalam tugasnya 
melakukan penyelesaian sengketa. Melalui hak-hak tersebut diharapkan perlindungan konsumen secara berlebihan yang mengabaikan kepentingan pelaku usaha dapat dihindari. Sejalan dengan hak-hak yang dimiliki oleh pelaku usaha, dalam menjalanjan usahanya pelaku usaha juga diwajibkan untuk melaksanakan kewajibannya sebagaimana diatur dalam Ps. 7 UUPK, adapun yang menjadi kewajiban pelaku usaha adalah sebagai berikut:

a. Beritikad baik dalam melakukan kegiatan usahanya;

b. Memberikan informasi yang benar, jelas dan jujur mengenai kondisi dan jaminan barang dan/atau jasa serta memberi penjelasan penggunaan, perbaikan dan pemeliharaan;

c. Memperlakukan atau melayani konsumen secara benar dan jujur serta tidak diskriminatif;

d. Menjamin mutu barang dan/atau jasa yang diproduksi dan/atau diperdagangkan berdasarkan ketentuan standar mutu barang dan/atau jasa yang berlaku;

e. Memberi kesempatan kepada konsumen untuk menguji, dan/atau mencoba barang dan/atau jasa tertentu serta memberi jaminan dan/atau garansi atas barang yang dibuat dan/atau yang diperdagangkan;

f. Memberi kompensasi, ganti rugi dan/atau penggantian atas kerugian akibat penggunaan, pemakaian dan pemanfaatan barang dan/atau jasa yang diperdagangkan;

g. Memberi kompensasi, ganti rugi dan/atau penggantian apabila barang dan/atau jasa yang diterima atau dimanfaatkan tidak sesuai dengan perjanjian.

Kewajiban pelaku usaha pada huruf (a) merupakan salah satu asas yang dikenal dalam hukum perjanjian, yakni asas itikad baik (Ps. 1338 ayat (3) KUHPdt). UUPK mewajibkan pelaku usaha beritikad baik dalam melakukan kegiatan usahanya. Dalam hal ini tampak bahwa itikad baik lebih ditekankan pada pelaku usaha, karena meliputi semua tahapan dalam melakukan kegiatan usahanya, sehingga dapat diartikan bahwa kewajiban pelaku usaha untuk beritikad baik dimulai sejak barang dirancang atau diproduksi sampai pada tahap purna transaksi. Bila dibandingkan dengan ketentuan mengenai kewajiban pelaku usaha dalam KUHPdt, nampaknya pengaturan kewajiban pelaku usaha dalam UUPK lebih spesifik karena selain harus melaksanakan usaha dengan itikad baik, pelaku usaha juga harus mampu menciptakan iklim usaha yang kondusif, tanpa persaingan yang curang antar pelaku usaha.

$\begin{array}{llr}\text { Berkaitan dengan } & \text { kewajiban } \\ \text { pelaku usaha untuk memberi } & \text { ma } \\ \text { kompensasi, ganti rugi } & \text { dan/atau }\end{array}$ penggantian sebagaimana ditentukan dalam ketentuan Ps. 7 huruh (f) dan (g) UUPK, serta kewajiban pelaku usaha untuk menanggung setiap produk yang diproduksi maupun diperdagangkan, khususnya penanggungan terhadap adanya cacat tersembunyi sebagaimana ditentukan dalam ketentuan Ps. 1491 KUHPdt dan Ps. 1504 KUHPdt, saat ini telah hadir suatu prinsip berdimensi Internasional yakni product liability. Untuk memahami lebih luas makna dari product liability maka akan dikutip beberapa definisi dari para ahli, yakni sebagai berikut :

Product liability is the area of law imposing liability upon manufacturers and other suppliers of goods for personal injury and property damage caused by product they sell (Mark E. Roszkowski, 1988: 436). Artinya bahwa tanggung jawab produk adalah bidang hukum 
yang memaksakan kewajiban pada produsen dan pemasok barang lainnya untuk bertanggung jawab atas cedera pribadi dan kerusakan harta benda yang disebabkan oleh produk yang mereka jual.

Refers to the legal liability of manufacturers and sellers to compensate buyers, user and even bystanders, for damages or injuries suffered because of defects in good purchased (Black Law Dictionary, 1990: 1209). Artinya bahwa product liability merupakan tanggung jawab produsen dan penjual untuk memberikan kompensasi kepada pembeli, pengguna ataupun pihak lain atas kerusakan atau cidera yang diderita karena produk tersebut mengandung cacat.

Product liability adalah tanggung jawab para produsen atas produk yang telah dibawanya kedalam peredaran, yang menimbulkan kerugian karena cacat yang melekat pada produk tersebut (Janus Sidabalok, 2010: 9).

Berdasarkan definisi-definisi diatas tampak bahwa product liability mempersoalkan tanggung jawab produsen dan/atau pelaku usaha atas timbulnya kerugian konsumen baik kerugian materiil maupun inmateriil sebagai akibat memakai atau mengkonsumsi produk cacat yang dihasilkan atau diperdagangkan produsen dan/atau pelaku usaha. Tujuan utama product liability adalah untuk memberikan perlindungan kepada konsumen serta agar terdapat pembebanan resiko yang adil antara produsen dan konsumen (Celina Tri Siwi Kristianti, 2011: 99). Product liability juga dimaksudkan untuk menekan lebih rendah tingkat kecelakaan karena produk cacat serta menyediakan sarana hukum ganti rugi bagi korban produk cacat yang tidak dapat dihindari. Dalam hal ini, yang dimaksud dengan produk cacat adalah setiap produk yang tidak dapat memenuhi tujuan pembuatannya baik karena kesengajaan maupun kealpaan dalam proses produksinya maupun disebabkan hal lainnya yang terjadi dalam peredarannya (Az. Nasution, 2002: 248).

Product liability merupakan lembaga yang tetap menggunakan konstruksi hukum tort (perbuatan melanggar hukum). Berdasarkan ketentuan product liability, pihak yang dianggap paling bertanggung jawab secara hukum adalah produsen. Dalam product liability, sistem tanggung jawab yang digunakan adalah strict liabilty, yang menekankan pada tidak adanya kewajiban bagi konsumen untuk membuktikan kesalahan pelaku usaha sebagai dasar penggantian kerugian dalam suatu gugatan dan/atau tuntutan (Ratna Artha Windari, 2015: 114). Meskipun tidak ada kewajiban konsumen untuk membuktikan kesalahan pelaku usaha, namun pihak korban atau konsumen yang akan menuntut kompensasi pada dasarnya diharuskan menunjukkan tiga hal yakni: pertama, bahwa produk tersebut telah cacat pada waktu diserahkan oleh produsen; kedua, bahwa cacat tersebut telah menyebabkan atau turut menyebabkan kerugian maupun kecelakaan; ketiga, adanya kerugian. Hal penting yang perlu digaris bawahi terkait sistem strict liability dalam product liability yakni bahwa produsen tetap dapat membebaskan diri dari tanggung jawabnya baik untuk sebagian ataupun keseluruhan apabila:

1. Produsen tidak mengedarkan produknya (put into circulation);

2. Cacat yang menyebabkan kerugian tidak ada pada saat produk diedarkan oleh produsen, dengan katalain cacat timbul dikemudian hari; 
3. Bilamana produk tersebut tidak dibuat oleh produsen baik untuk dijual atau diedarkan untuk tujuan ekonomis maupun dibuat atau diedarkan dalam rangka bisnis;

4. Bilamana terjadinya cacat adalah sebagai akibat dari keharusan memenuhi kewajiban yang ditentukan dalam peraturan yang dikeluarkan oleh pemerintah;

5. Bilamana dapat dibuktikan secara ilmiah dan teknis (state of scientic and technical knowledge, state of art defense) bahwa pada saat produk tersebut diedarkan tidak mungkin terjadi cacat;

6. Dalam hal produsen dari suatu komponen, bahwa cacat tersebut disebabkan oleh desain dari produk itu sendiri dimana komponen telah dicocokkan atau disebabkan kesalahan pada petunjuk yang diberikan oleh pihak produsen tersebut;

7. Bila pihak yang mengalami kerugian atau pihak ketiga turut menyebabkan terjadinya kerugian tersebut (contributory negligence);

8. Kerugian yang terjadi diakibatkan oleh acts of god atau force majeur (Johanes Gunawan, 1994: 7)

Sebagaimana telah disampaikan sebelumnya pada bagian pendahuluan, adapun ketentuan prinsip product liability secara Nasional di Indonesia diatur dalam UUPK. UUPK mengakomodasi dua prinsip penting, yakni tanggung jawab produk (product liability) dan tanggung jawab professional (professional liability) (Zulham, 2013: 99). Ketentuan product liability dalam UUPK tercermin dalam BAB VI khususnya ketentuan Ps. 19 UUPK, Ps. 23 UUPK, dan Ps. 28 UUPK. Berdasarkan Ketentuan Ps. 19 UUPK, adapun yang menjadi tanggung jawab pelaku usaha adalah sebagai berikut:
1. Pelaku usaha bertanggung jawab memberikan ganti rugi atas kerusakan, pencemaran, dan atau kerugian konsumen akibat mengkonsumsi barang dan atau jasa yang dihasilkan atau diperdagangkan;

2. Ganti rugi sebagaimana dimaksud pada ayat (1) dapat berupa pengembalian uang atau penggantian barang dan/atau jasa yang sejenis atau setara nilainya, atau perawatan kesehatan dan/atau pemberian santunan yang sesuai dengan ketentuan peraturan perundangundangan yang berlaku;

3. Pemberian gantirugi dilaksanakan dalam tenggang waktu 7 (tujuh) hari setelah tanggal transaksi;

4. Pemberian ganti rugi sebagaimana dimaksud pada ayat (1) dan ayat (2) tidak menghapuskan kemungkinan adanya tuntutan pidana berdasarkan pembuktian lebih lanjut mengenai adanya unsur kesalahan.

5. Ketentuan sebagaimana dimaksud pada ayat (1) dan ayat (2) tidak berlaku apabila pelaku usaha dapat membuktikan bahwa kesalahan tersebut merupakan kesalahan konsumen.

Ketentuan Ps. 19 ayat (1) UUPK memberi arti bahwa pelaku usaha harus memberi kompensasi atau ganti kerugian atas kerugian konsumen yang diakibatkan produk cacat tanpa harus membebani konsumen untuk membuktikan kesalahan pelaku usaha (Lukmanul Hakim, 2010: 45). Meskipun istilah cacat tidak digunakan dalam ketentuan Ps. 19 UUPK, namun mengingat ketentuan ini mengatur mengenai tanggung jawab pelaku usaha dimana produk cacat dapat menimbulkan kerugian pada konsumen, dengan demikian ketentuan Ps. 19 UUPK juga merupakan suatu bentuk 
tanggung jawab terhadap kerugian konsumen akibat produk cacat sebagaimana ditentukan dalam product liability. Ketentuan Ps. 19 UUPK selanjutnya dikembangkan pada Ps. 23 UUPK yang menyatakan bahwa pelaku usaha yang menolak dan atau tidak memberi tanggapan dan atau tidak memenuhi ganti rugi atas tuntutan konsumen sebagaimana dimaksud dalam Ps. 19 ayat (1), ayat (2), ayat (3), dan ayat (4), dapat digugat melalui Badan Penyelesaian Sengketa Konsumen (selanjutnya disingkat BPSK) atau mengajukan ke badan peradilan di tempat kedudukan konsumen. Ketentuan lanjutan terkait Ps. 23 UUPK adalah Ps. 28 UUPK yang menyatakan bahwa pembuktian terhadap ada tidaknya unsur kesalahan dalam gugatan ganti rugi sebagaimana dimaksud dalam Ps. 19, Ps. 22, dan Ps. 23 merupakan beban dan tanggung jawab pelaku usaha. Hal ini berarti bahwa adapun sistem pembuktian dalam gugatan ganti rugi konsumen adalah sistem pembuktian terbalik karena pembuktian dibebankan pada pelaku usaha. Sistem beban pembuktian terbalik juga digunakan bilamana kasus pelindungan konsumen diangkat sebagai kasus pidana, hal ini memberi arti bahwa meskipun ganti rugi telah diberikan, namun tidak akan menghapus kemungkinan adanya tuntutan pidana berdasarkan pembuktian lebih lanjut mengenai adanya unsur kesalahan.

Berdasarkan pemaparan diatas terkait dasar hukum penerapan prinsip product liability di Indonesia, apabila dikaitkan dengan implementasinya dalam transaksi smart phone di Denpasar, adapun perbuatan pelaku usaha tersebut adalah merupakan suatu bentuk perbuatan melanggar hokum karena pelaku usaha melakukan pelanggaran terhadap ketentuan product liability sebagaimana tercermin dalam Ps. 1491 KUHPdt, Ps. 1504 KUHPdt, Ps. 19 UUPK, Ps. 23 UUPK, dan Pasal 28 UUPK. Perbuatan melanggar hukum sebagaimana ditentukan dalam Ps. 1365 KUHPdt sebenarnya tidak hanya berorientasi pada pelanggaran terhadap kaidah-kaidah tertulis, yakni perbuatan yang bertentangan dengan kewajiban hukum si pelaku dan melanggar hak subyektif orang lain, melainkan juga pelanggaran terhadap kaidah tidak tertulis yakni kaidah yang mengatur tata susila, kepatutan, ketelitian, dan kehati-hatian yang seharusnya dimiliki seseorang dalam pergaulan hidup di masyarakat atau terhadap harta benda warga masyarakat (Rosa Agustina, at. al, 2012: 8). Adapun tuntutan yang dapat diajukan konsumen berdasarkan perbuatan melawan hukum yang dilakukan pelaku usaha yakni sebagai berikut:

1. Ganti rugi dalam bentuk uang atas kerugian yang ditimbulkan;

2. Ganti rugi dalam bentuk natura atau dikembalikan dalam keadaan semula;

3. Pernyataan bahwa perbuatan yang dilakukan adalah melawan hukum;

4. Melarang dilakukannya perbuatan tertentu;

5. Meniadakan sesuatu yang diadakan secara melawan hukum; dan

6. Pengumuman dari keputusan atau dari suatu yang telah diperbaiki (Ibid: 15).

Atas dasar pelanggaran hukum yang telah dilakukan oleh pelaku usaha smart phone di Denpasar, maka perlu untuk dikaji mengenai efektifitas penerapan prinsip product liability sebagaimana diatur dalam Ps. 19 UUPK. Berbicara mengenai efektifitas suatu Peraturan Perundang-Undangan dan/atau aturan hukum sangat bergantung pada substance, structure, 
dan legal culture (Lawrence M. Friedman, 1969: 15). Oleh karena itu, adapun pengkajian mengenai efektifitas sebagaimana dimaksud diatas akan didasarkan pada teori sistem hukum (legal system theory) yang dikemukakan oleh Lawrence Meir Friedman. Secara garis besarnya, adapun legal system theory menentukan bahwa berhasil atau tidaknya penegakan hukum bergantung pada 3 (tiga) komponen penting, yakni:

1. Substansi hukum, yakni dapat diartikan sebagai produk yang dihasilkan oleh orang yang berada dalam sistem hukum seperti Undang-Undang dan bahkan mencakup hukum yang hidup dalam masyarakat (living law), jadi tidak sebatas aturan yang ada dalam Perundang-Undangan (law books). Secara garis besarnya substansi hukum menentukan dapat atau tidaknya hukum itu dilaksanakan, dalam artian bahwa hukum dapat dilaksanakan apabila ada aturan yang mengatur.

2. Struktur hukum, meliputi aparat penegak hukum maupun instansi yang terkait dalam pelaksanaan dan pengawasan aturan hukum yang telah berlaku. Aturan hukum tidak dapat ditegakkan apabila tidak ada aparat penegak hukum yang melaksanakan dan mengawasi aturan hukum bersangkutan. Berdasarkan Undang-Undang No. 8 Tahun 1981 tentang Hukum Acara Pidana struktur hukum meliputi; Kepolisian, Kejaksaan, Pengadilan dan Badan Pelaksana Pidana (Lapas).

3. Budaya hukum, merupakan sikap manusia terhadap hukum dan sistem hukum-kepercayaan, nilai, pemikiran, serta harapannya. Budaya hukum juga merupakan pemikiran sosial dan kekuatan sosial yang menentukan bagaimana hukum digunakan, disalahgunakan, dan dihindari. Budaya hukum sangat berkaitan dengan kesadaran hukum masyarakat, semakin tinggi kesadaran hukum masyarakat maka akan tercipta budaya hukum yang baik.

Terhadap pelanggaran yang dilakukan pelaku usaha smart phone di Denpasar dalam pelaksanaan ketentuan product liability, apabila dikaji berdasarkan Legal System Theory, maka dapat ditentukan sebagai berikut:

1. Bahwa secara substansi, ketentuan product liability di Indonesia telah diatur Pada Ps. 1491 KUHPdt, Ps. 1504 KUHPdt, Ps. 19 UUPK, Ps. 23 UUPK, dan Ps. 28 UUPK sehingga hal ini memberi konsekwensi bahwa setiap pelanggaran terhadap ketentuan product liability di Indonesia dapat dikenakan sanksi hukum berupa ganti kerugian terhadap kerugian yang diderita konsumen sebagaimana ditentukan dalam Ps. 19 UUPK dan/atau dapat digugat melalui Badan Penyelesaian Sengketa Konsumen atau mengajukan gugatan ke Badan Peradilan Umum di tempat kedudukan konsumen sebagaimana ditentukan dalam Ps. 23 UUPK dengan pembuktian yang dibebankan pada pelaku usaha sebagaimana ditentukan dalam Ps. 28 UUPK.

2. Bahwa secara struktural, Adapun struktur yang berwenang dalam melakukan pengawasan terhadap perlindungan konsumen berdasarkan ketentuan Ps. 44 ayat (3) huruf (e) UUPK yakni Lembaga Perlindungan Konsumen Swadaya Masyarakat (dalam bentuk LSM), Pemerintah (yang dalam hal ini Dinas Perindustrian dan Perdagangan), dan masyarakat. Adapun ke-3 (tiga) elemen ini saling 
bersinergi dalam melaksanakan peranannya dan berkordinasi dengan Badan Perlindungan Konsumen Nasional yang berfungsi menerima pengaduan tentang perlindungan konsumen dari Lembaga Perlindungan Konsumen Swadaya Masyarakat, pelaku usaha, maupun masyarakat. Meski secara struktural sudah sangat jelas pihakpihak yang berwenang untuk melakukan pengawasan, namun nampaknya peranan struktur dalam hal ini belum maksimal. Hal ini disebabkan adanya hambatan yang dihadapi yakni sangat sulit untuk melakukan pengawasan secara langsung dengan mendatangi setiap pelaku usaha mengingat banyaknya jumlah pelaku usaha yang tersebar, sehingga tidak mungkin untuk dapat dilakukan pengawasan terhadap keseluruhan pelaku usaha tersebut. Sejauh ini penyelenggaraan perlindungan konsumen hanya didasarkan pada laporan dari masyarakat maupun pengaduan konsumen terkait adanya dugaan pelanggaran yang dilakukan oleh pelaku usaha, namun hal ini juga tidak efektif karena masyarakat maupun konsumen terkesan enggan untuk mengadukan dugaan pelanggaran yang dilakukan pelaku usaha.

3. Secara kultural, budaya hukum sangat berkaitan dengan kesadaran hukum masyarakat. Namun demikian, meski masyarakat memiliki kesadaran hukum hal ini belum menjamin bahwa masyarakat akan selalu mentaati suatu aturan hukum. Hal ini dapat dilihat dari tindakan pelaku usaha untuk menghindari tanggung jawabnya dengan mencantumkan klausula eksonerasi yang menyatakan penolakan pengembalian barang oleh pelaku usaha dalam setiap bukti transaksinya. Dalam hal ini sangat jelas bahwa pelaku usaha sebenarnya paham akan tanggung jawab yang dibebankan kepadanya bilamana sewaktu-waktu produk yang diproduksi dan diperdagangkannya merugikan konsumen, atas dasar pemahamannya maka pelaku usaha justru berusaha menghindari tanggung jawab tersebut. Hal ini mencerminkan itikad yang tidak baik dari pelaku usaha dalam menjalankan usahanya. Hal ini bertentangan dengan salah satu kewajiban pelaku usaha sebagaimana ditentukan dalam Ps. 7 huruf (a) UUPK.

Atas dasar ke 3 (tiga) komponen Legal System Theory yang telah dijabarkan diatas, maka dapat dikatakan bahwa penerapan prinsip product liability oleh pelaku usaha smart phone di Denpasar belum efektif, dimana ketidak efektifannya dipengaruhi oleh struktur yang belum memadai serta budaya hukum pelaku usaha yang masih sangat lemah.

\section{Relevansi Pencantuman Klausula Eksonerasi Dalam Transaksi Smart Phone di Denpasar}

Secara teoritis hingga saat ini perjanjian baku atau perjanjian yang mengandung klausula baku masih menjadi perdebatan khususnya dalam kaitannya dengan asas kebebasan berkontrak dan syarat sahnya perjanjian sebagaimana ditentukan dalam Ps.1320 KUHPerdata. Berdasarkan ketentuan Ps. 1320 KUHPerdata, suatu perjanjian adalah sah apabila telah memenuhi empat syarat yakni: adanya kesepakatan dua belah pihak atau lebih, adanya kecakapan untuk membuat suatu 
perjanjian, adanya suatu hal tertentu, dan suatu sebab yang halal. Syarat pertama dan kedua merupakan syarat subjektif karena berkenaan dengan diri orang atau subjek yang membuat kontrak, pelanggarannya memberi konsekuensi perjanjian itu dapat dimohonkan pembatalannya. Syarat ketiga dan keempat merupakan syarat objektif, pelanggarannya memberi konsekuensi perjanjian itu batal demi hukum (Agus Yudha Hernoko, 2011: 160). Meskipun perjanjian baku dinilai mengenyampingkan asas kebebasan berkontrak dan syarat sahnya suatu perjanjian, namun harus diakui bila perjanjian baku dibutuhkan dalam dunia perdagangan yang semakin maju, dimana penggunaan perjanjian baku dapat mempersingkat waktu bernegosiasi. Satu hal yang perlu diperhatikan adalah bukan melarang penggunaan perjanjian baku, melainkan melarang pencantuman klausulaklausula tertentu dalam perjanjian baku tersebut.

Sebagaimana telah disinggung pada bagian pendahuluan, adapun pencantuman klausula baku diatur dalam ketentuan Ps. 18 UUPK yang merupakan ketentuan khusus (lex specialis) terhadap ketentuan Ps. 1320 jo. Ps. 1337 KUHPerdata. Artinya bahwa meskipun syarat sahnya perjanjian sebagaimana ditentukan dalam Ps. 1320 KUHPdt tidak ditemukan lagi dalam suatu perjanjian baku, namun demikian setiap pelaku usaha dapat menerapkan perjanjian baku selama tidak mengandung kausa atau sebab terlarang yang terwujud dalam bentuk prestasi yang tidak diperkenankan untuk dilakukan menurut hukum, kesusilaan, dan ketertiban umum, meskipun memuat ataupun tidak memuat klausula baku sebagaimana diatur dalam Ps. 18 ayat (1) dan (2) UUPK. Adapun yang menjadi tujuan dari ketentuan Ps. 18 ayat (1) UUPK sebagaimana dimaksud diatas adalah untuk mencegah pelaku usaha mencantumkan klausula eksonerasi, yakni klausula yang berisi tentang pembatasan tanggung jawab dan/atau mencegah pelaku usaha untuk mencantumkan klausula yang mengandung syarat khusus membebaskan dirinya dari tanggung jawab terhadap akibat yang merugikan konsumen yang timbul dari pelaksanaan perjanjian.

Terkait dengan relevansi pencantuman klausula eksonerasi dalam perjanjian baku yang diterapkan oleh pelaku usaha di Denpasar, setelah diamati diketahui bahwa hampir semua pelaku usaha mencantumkan klausula eksonerasi pada perjanjian baku yang dibuat dalam bentuk formulir berupa nota, faktur dan/atau invoice. Adapun klausula eksonerasi yang dicantumkan oleh pelaku usaha sebagaimana dimaksud diatas, seragam menyatakan bahwa barang yang telah dibeli tidak dapat ditukar atau dikembalikian. Pernyataan pelaku usaha dalam bentuk klausula eksonerasi ini tentu ditujukan untuk membatasi dan bahkan menghindari tanggungjawabnya bilamana konsumen mengalami kerugian. Dapat dikatakan demikian karena klausula yang dicantumkan tersebut mengandung syarat yang khusus membebaskan pelaku usaha dari tanggung jawab terhadap akibat yang merugikan konsumen, meskipun tidak secara tegas disampaikan dalam klausula tersebut. Bilamana konsumen mengalami kerugian akibat menggunakan suatu produk barang, misal barang yang telah dibeli tidak dapat difungsikan sebagaimana mestinya dan konsumen hendak mengembalikan ataupun menukar barang tersebut dengan barang sejenis kepada pelaku usaha, namun dengan 
adanya klausula yang menyatakan bahwa barang yang telah dibeli tidak dapat ditukar atau dikembalikian, disini sangat jelas terlihat bahwa ada upaya dari pelaku usaha untuk menghindari tanggung jawabnya bilamana sewaktuwaktu konsumen mengalami kerugian.

Apabila dikaji berdasarkan ketentuan pencantuman klausula baku dalam UUPK, maka dapat dinyatakan bahwa klausula yang dicantumkan pelaku usaha telah memenuhi unsur terlarang dalam ketentuan Ps. 18 ayat (1) huruf (b) UUPK. Pernyataan pelaku usaha dalam bentuk klausula eksonerasi sebagaimana dimaksud diatas merupakan bentuk pelepasan tanggung jawab secara eksplisit terhadap setiap kerugian konsumen yang timbul dikemudian hari akibat menggunakan produknya. Klausula eksonerasi sebenarnya dapat dirumuskan hanya dalam keadaan memaksa (force majeur), misalnya dalam hal untuk mengantisipasi bilamana suatu objek perjanjian jual-beli berupa barang yang pembayarannya dilakukan secara angsuran musnah karena terbakar. Dalam keadaan yang demikian, meskipun kebakaran yang menyebabkan musnahnya objek perjanjian bukan merupakan kesalahan para pihak baik pelaku usaha maupun konsumen, namun dalam hal ini pelaku usaha dapat mencantumkan klausula eksonerasi yang menyatakan bahwa pembeli diwajibkan melunasi harga yang belum lunas.

Memperhatikan serta mencermati maksud dari perumusan klausula eksonerasi oleh pelaku usaha, adapun perumusannya tidaklah didasarkan pada keadaan memaksa (force majeur) melainkan semata-mata hanya untuk membebaskan diri dari kewajibannya untuk bertanggung jawab atas setiap kerugian konsumen yang ditimbulkan oleh produk yang diproduksi maupun diperdagangkannya.

kecendrungan konsumen untuk menerima keberadaan klausula eksonerasi sebagaimana dimaksud diatas semata-mata hanya atas dasar dorongan kebutuhan, apabila konsumen tidak menerima maka konsumen tidak akan mendapatkan produk yang dibutuhkannya. Dengan demikian, dalam hal ini dapat diketahui bahwa sebenarnya ada unsur keterpaksaan konsumen untuk menerima keberadaan klausula tersebut. Unsur keterpaksaan sebagaimana dimaksud adalah merupakan suatu bentuk cacat kehendak dari konsumen sebagai akibat penyalahgunaan keadalan yang dilakukan oleh pelaku usaha baik terhadap keunggulan ekonomis yakni karena konsumen berada dalam situasi terjepit akan kebutuhannya, maupun terhadap keunggulan kejiwaan yakni dalam situasi terjepit konsumen dengan terpaksa menerima keberadaan klausula eksonerasi yang dicantumkan pelaku usaha. Kondisi seperti ini menggambarkan bahwa konsumen berada dalam keadaan yang tidak diuntungkan akibat penerapan klausula eksonerasi dalam suatu perjanjian baku. Sejalan dengan kondisi tersebut, tepatlah kiranya apabila konsumen diposisikan sebagai pihak yang lemah seperti diakui secara Internasional dalam Resolusi Majelis Internasional PBB, No.A/RES/39/248 Tahun 1985 tentang Guidelines for Consumer Protection (Susanti Adi Nugroho, 2008: 2).

Berdasarkan apa yang telah diuraikan sebelumnya, bahwa klausula eksonerasi yang dirumuskan pelaku usaha tidak didasarkan pada force majeur, serta klausula sebagaimana dimaksud diatas telah memenuhi unsur terlarang dari Ps. 18 ayat (1) huruf (b) UUPK, dengan demikian adapun klausula eksonerasi yang dicantumkan 
pelaku usaha dalam setiap perjanjian baku yang dibuat dalam bentuk formulir berupa nota, faktur dan/atau invoice adalah tidak relevan sehingga dinyatakan batal demi hukum berdasarkan ketentuan Ps. 18 ayat (3) UUPK. Meskipun ketentuan Ps. 18 ayat (3) UUPK menyatakan bahwa setiap klausula baku yang ditetapkan oleh pelaku usaha adalah batal demi hukum apabila memenuhi unsur yang dilarang dalam ketentuan Ps. 18 ayat (1) dan (2), namun dalam prakteknya hingga saat ini klausula baku yang mengandung syarat khusus dengan tujuan membebaskan pelaku usaha dari tanggung jawab terhadap akibat yang merugikan konsumen (klausula eksonerasi) masih dengan bebas diterapkan dan diberlakukan oleh pelaku usaha.

Melihat kondisi yang seperti ini, selain batal demi hukumnya klausula baku dan/atau klausula eksonerasi yang memenuhi unsur terlarang dari Ps.18 ayat (1) dan (2) UUPK, sebenarnya terhadap perjanjian baku yang mengandung klausula sebagaimana dimaksud diatas dapat dimohonkan pembatalannya berdasarkan prinsip penyalahgunaan keadaan (misbruik van omstadigheden). Berdasarkan Pasal 2 Woeker Ordonantie tahun 1938 ditentukan mengenai pembatasan terhadap penyalahgunaan keadaan yang dapat merugikan konsumen, para hakim diberikan kewenangan untuk mengurangi kewajiban pihak yang dirugikan atau membatalkan perjanjian dalam hal hakim menemukan ketidak seimbangan antara kewajibankewajiban para pihak (Ahmadi Miru, \& Sutarman Yodo, 2008: 123). Penyelesaian sengketa berdasarkan ajaran penyalahgunaan keadaan dapat diterapkan di Indonesia dengan mengacu pada Putusan Mahkamah Agung RI No.1904 K/Sip 1982, tanggal
28 Januari 1984. Terkait pembatalan perjanjian baku berdasarkan ajaran penyalahgunaan keadaan, adapun pembatalannya dapat dimohonkan dengan mengajukan tuntutan melalui Pengadilan Negeri dengan dalil bahwa adanya pembatasan kehendak yang bebas dari konsumen untuk menentukan persetujuannya dalam perjanjian baku, sehingga para pihak menjadi tidak berada dalam posisi yang seimbang untuk menentukan isi perjanjian karena pelaku uasaha telah melakukan penyalahgunaan keadaan terhadap keunggulan ekonomis maupun kejiwaan. Adapun dasar tuntutan yang diajukan yakni perbuatan melawan hukum.

\section{Simpulan}

Berdasarkan apa yang telah diuraikan diatas, dapat disimpulkan beberapa hal sebagai berikut:

1. Penerapan prinsip product liability terhadap konsumen belum efektif, hal ini dilatarbelakangi masih banyaknya pelaku usaha yang dengan sengaja melakukan pelanggaran terhadap ketentuan tersebut, pelaku usaha justru mencantumkan klausula eksonerasi yang menyatakan penolakan pengembalian barang oleh konsumen dalam setiap perjanjian baku yang dibuat dalam bentuk formulir berupa nota, faktur dan/atau invoice sebagai upaya menghindari tanggung jawab kepada konsumen bilamana sewaktu-waktu konsumen mengalami kerugian akibat produk yang diproduksi dan/atau diperdagangkannya, disamping itu peran serta segenap komponen masyarakat sebagai pengawas terhadap penyelenggaraan perlindungan konsumen juga masih lemah akibat dari kurangnya 
pemahaman akan pentingnya perlindungan terhadap konsumen, khususnya mengenai hak-hak konsumen.

2. Pencantuman klausula eksonerasi dalam perjanjian baku yang dibuat dalam bentuk formulir berupa nota, faktur dan/atau invoice oleh pelaku usaha tidak relevan karena tidak didasarkan pada force majeur dan telah memenuhi unsur terlarang dari Ps. 18 ayat (1) huruf (b) UUPK, dimana klausula sebagaimana dimaksud mengandung syarat khusus yang ditujukan untuk membebaskan pelaku usaha dari tanggung jawab terhadap akibat yang merugikan yang timbul dari pelaksanaan perjanjian, sehingga terhadap klausula yang demikian adalah batal demi hukum dan/atau dapat dilakukan pembatalan perjanjian berdasarkan prinsip penyalahgunaan keadaan (misbruik van omstadigheden) melalui Pengadilan Negeri dengan dasar tuntutan perbuatan melawan hukum.

\section{Saran}

Berdasarkan permasalahan yang terjadi, maka dapat diberikan beberapa saran sebagai berikut:

1. Terkait lemahnya peran serta masyarakat dalam pengawasan terhadap penyelenggaraan perlindungan konsumen sebagai akibat dari kurangnya pemahaman akan pentingnya perlindungan terhadap konsumen khususnya mengenai hak-hak konsumen, maka perlu dilakukan pemberdayaan konsumen guna meningkatkan kesadaran, kemampuan dan kemandirian konsumen untuk melindungi diri dari akses negatif pemakaian barang maupun jasa, hal ini akan dapat terwujud melalui komitmen antara pemerintah selaku penghasil aturan hukum berupa Peraturan PerundangUndangan, Aparat selaku pelaksana dan pengawas aturan hukum yang telah berlaku, serta seluruh komponen masyarakat dalam suatu sistem sosial yang menjadi roh pembentukan suatu budaya hukum, dimana budaya hukum merupakan pemikiran sosial dan kekuatan sosial yang menentukan bagaimana hukum digunakan, disalahgunakan, dan dihindari sehingga budaya hukum sangat berkaitan dengan kesadaran hukum masyarakat.

2. Terkait pembatalan perjanjian berdasarkan prinsip penyalahgunaan keadaan (misbruik van omstadigheden), meskipun Putusan Mahkamah Agung RI No.1904 K/Sip 1982, Tanggal 28 Januari 1984 dapat digunakan sebagai acuan untuk melakukan pembatalan terhadap perjanjian yang lahir akibat penyalahgunaan keadaan seperti penerapan perjanjian baku yang mengandung klausula eksonerasi, namun demikian prinsip penyalahgunaan keadaan (misbruik van omstadigheden) perlu diatur kedalam suatu Peraturan Perundang-Undangan yang khusus di Indonesia mengingat bahwa penyalahgunaan keadaan juga merupakan intrumen hukum yang tetap menggunakan dasar tuntutan perbuatan melawan hukum, dimana perbuatan melawan hukum tidak hanya merupakan pelanggaran terhadap norma ataupun kaidah hukum tertulis melainkan juga meliputi pelanggaran terhadap kaidah tidak tertulis seperti tata susila, ketelitian dan kehati-hatian yang seharusnya dimiliki seseorang 
dalam pergaulan hidup di masyarakat.

\section{Daftar Pustaka}

Agustina, Rosa, at. Al, 2012, Hukum Perikatan (Law of Obligations), Edisi-1, Cetakan ke-1, Pustaka Larasan, Denpasar.

Amiruddin dan Asikin, H. Zainal, 2010, Pengantar Metoda Penelitian Hukum, Edisi-1, Cetakan ke-5, PT. Raja Grafindo Persada, Jakarta.

Badrulzaman, Mariam Darus, 2001, Kompilasi Hukum Perikatan, Cetakan ke-1, Citra Aditya Bakti, Bandung.

Black, Henry Campbell, 1990, Black's Law Dictionary, St Paul Minn: West Publishing Co.

Friedman, Lawrence M., 1969, The Legal System: Social Science Perspektif Russel Soge Foundation, New York.

Gunawan, Johanes, 1994, Product Liability Dalam Hukum Bisnis Indonesia, orasi ilmiah dalam rangka Dies Natalis XXXIX, Unika Parahyangan Bandung.

H.S, Salim, 2003, Hukum Kontrak Teori dan Teknik Penyusunan Kontrak, Sinar Grafika, Jakarta.

Hakim, Lukmanul, 2010, Tanggung Jawab Produsen Dalam Perdagangan Bebas, Jurnal Ilmiah Manajemen dan Akuntansi STIE AMA Salatiga, Vol. 3. No. 6. Salatiga.

Hernoko, Agus Yudha, 2011, Hukum Perjanjian (Asas Proporsionalitas Dalam Kontrak Komersial), Edisi-1, Cetakan ke-2, Kencana Prenada Media Group, Jakarta.

Kristianti, Celina Tri Siwi, 2011, Hukum Perlindungan Konsumen, Edisi-1, Cetakan ke-3, Sinar Grafika, Jakarta.

Miru, Ahmadi, \& Yodo, Sutarman, 2008, Hukum Perlindungan Konsumen,
Edisi-1, Cetakan ke-5, PT. RajaGrafindo Persada, Jakarta.

Mukhtar, 2013, Metode Praktis Penelitian Deskriptif Kualitatif, Edisi-1, Cetakan ke-1, Referensi (GP Press Group), Jakarta.

Nasution Az., 2002, Hukum Perlindungan Konsumen Suatu Pengantar, Edisi-1, Cetakan ke-2, Diadit Media, Jakarta.

Nugroho, Susanti Adi, 2008, Proses Penyelesaian Sengketa Konsumen Ditinjau Dari Hukum Acara Serta Kendala Implementasinya, Edisi-1, Cetakan ke-1, Kencana Prenada Media Group, Jakarta.

Panggabean, H.P., 2010, Penyalahgunaan Keadaan Sebagai Alasan Baru Untuk Pembatalan Perjanjian, Edisi Revisi Ke-2, Prodeo Et Patria, Jakarta.

Rahman, Hasanuddin, 2000, Legal Drafting, Cetakan ke-1, Citra Aditya Bakti, Bandung.

Rasjid, Fadjar Efendy, Android: Sistem Operasi Pada Smartphone, http://www.ubaya.ac.id/2014/co ntent/articles_detail/7/Android-Sistem-Operasi-padaSmartphone.html, 30 Januari 2017. Roszkowski, Mark E, 1988, Business Law, Principles, Cases and Policy, Second Edition, Harper Collins Publisher, USA.

Sidabalok, Janus, 2010, Hukum Perlindungan Konsumen di Indonesia, Cetakan ke-2, PT. Citra Aditya Bakti, Bandung.

Soekanto, Soerjono, 2012, Pengantar Penelitian Hukum, Cetakan ke-3, UI-Press, Jakarta.

Soekanto, Soerjono dan Mahmudji, Sri, 2013, Penelitian Hukum Normatif Suatu Tinjauan Singkat, Edisi-1, Cetakan ke-15, PT. Raja Grafindo Persada, Jakarta.

Sutedi, Adrian, 2008, Tanggung Jawab Produk Dalam Hukum 
Perlindungan Konsumen, Edisi-1, Cetakan ke-2, Ghalia Indonesia, Bogor.

Windari, Ratna Artha, Pertanggungjawaban Mutlak (Strict Liability) Dalam Hukum Perlindungan Konsumen, Jurnal Komunikasi Hukum, Volume 1, Nomor 1, Pebruari 2015.

Zulham, 2013, Hukum Perlindungan Konsumen, Edisi-1, Cetakan ke-1, Kencana Prenada Media Group, Jakarta. 